are notably conservative in their concerns, or that the pattern is largely shaped by the availability of tutors. The largest number of extra-mural classes in Wales was in religion, and clergy and ministers of religion formed the second highest category in the analysis of tutors.

The number of full-time tutors showed a slight increase over the previous years, and was almost the same as in 1956-57. Nevertheless, the increase in full-time tutors did not match the increase in courses, and consequently a larger number of part-time tutors was engaged, 3,838 compared with 3,512 in the previous year. This was a continuation of the trend noticeable during the past few years. The proportion of part-time tutors who are members of a university staff has at the same time declined slightly, but steadily, from 48 per cent in $1956-57$ to 45 per cent in 1959-60.

Since the War, extra-mural work has expanded into fields such as archæology, music and the visual arts in which, though it is aecepted that they are properly subjects of university study, a considerable proportion of the practitioners and exponents are to be found outside the universities. Moreover, dons become busier and more heavily committed. Belfast refers to the "growing reluctance of university teachers to make weekly journeys", Newcastle comments that "the prevailing apparent disinclination on the part of internal university lecturers to commit themselves to the longer course, especially if travelling is involved", and both Liverpool and London regret the transport difficulties which make it hard, or even impossible, for members of the internal university staff to travel to the remoter parts of their extra-mural areas. At a time when students have become more mobile, dons have become less so. This is a minor, less-prominent, feature of the mid-twentieth century social revolution; it creates new problems in maintaining the university complexion of extra-mural work.

Specialized courses which relate to a professional or vocational interest are now widespread. Manchester has a one-year training scheme for hospital welfare workers, a one-year public administration. course for overseas Government servants, and a course on background to management for business executives which received the commendation of the Human Sciences Committee of the Department of Scientific and Industrial Research. At Liverpool there were several courses in the natural sciences at the postgraduate level, two of them, in applied mathematics and experimental botany, leading to a certificate. London has approved the introduction of a three-year course of study leading to a certificate in transport studies, and 1959-60 saw the beginning of the course for the diploma in the history of music. At Leeds, courses in such subjects as textiles, engineoring, mining and fuel were arranged in association with internal departments of the University, and other courses were arranged for members of the staffs of the Home Office, the Prison Commission, the National Association for Mental Health, the National Coal Board, and the National Union of Mineworkers.

Courses of this kind are carrying universities into new fields where extra-mural departments are having to institute their own research. Leeds has received a grant from the Nuffield Provincial Hospitals Trust for work on the staffing of the hospital service, Liverpool appointed a research worker to study the impact of social change on adult education, and Oxford has embarked on a three-year scheme of research and experimental work in the field of trade union education.

These kinds of courses appeal rather to individual students than to pre-existing social groups, although it is always hoped that every class will grow into a cohesive social group. People move about much more often than they used to, and groups are less permanent. Continuity and progression of study needs to be thought of in terms of the individual more than of the group. The Leicester report, in its survey of the thirty years 1929-1959/60, contains a statement which would command at least partial acceptance generally:

"There has also been a decided change in the ethos of the department's classes. Formerly, it was markedly social, now it is markedly individual. Classes and courses still grow into social unities, but this is now an incidental growth and it has not the educational significance which it once had. Rarely now do classes and courses become schools of citizenship as well as vehicles for teaching and learning in specific disciplines."

Another respect in which the change is noticeable is the educational background of students. The percentage of weekly wage-earners and of those with only an elementary or secondary modern education has fallen more than 40 to less than 10 , and the percentage of professional workers and of those with a college or university education has risen from less than 10 to more than 40 . Of the thousand students attending grant-aided extension classes at Leeds, more than 40 per cent had been to a university, teacher training college or technical college, and another 30 per cent had attended school at least until the age of sixteen. Almost half of them were under the age of thirty-six.

There are numerous examples of extra-mural classes undertaking field-work which has added to knowledge in botany, zoology, archrology and history. Under the tutelage of the Durham ExtraMural Board, for example, a group of 15 students has investigated the site of a medieval village at West Whelpington, and their findings make a distinct contribution to the comparatively now venture of British archæology into the later Middle Ages.

\title{
MUSEUMS AND GALLERIES
}

$\mathrm{T}$ WE recent report of the Standing Commission on Museums and Galleries stresses the responsibility of the British Government with regard to these institutions, and urges some immediate action*.

* Standing Commission on Museums and Galleries. Sixth Report, 1958-1960. Pp. iv +64. (London: H.M.S.O., 1961.) 48. net.
Contrary to past practice, this sixth report covers only two years (1959 and 1960) instead of the usual quinquennial period. In emphasizing the need for more frequent reports, the Commission feels that this is a period of active rehabilitation in museums after a time of severe financial stringency. There is an 
increased public interest in them and higher standards are now expected.

Although dealing chiefly with the national museums, the provincial institutions will welcome the recommendation of the Commission that the grant (now at $£ 25,000$ ) administered by the Victoria and Albert Museum for purchases should be increased in the next financial year.

With regard to buildings, there are at least thirteen projects which are to be regarded as of particular urgency. These include reconstruction of the wardamaged galleries at the British Museum, planning and construction of the final quarter of the Tate Gallery, erection of a new herbarium and library wing at Kew, construction of north-east and northwest wings of the Royal Scottish Museum, work on a west wing of the National Museum of Wales and extension of the Museum block of the Welsh Folk Museum.

The Commission urges museums to aim at a steady and rapid improvement in all thoir services and recommends that staff should be appointed to carry this out. It considers that these services should including cataloguing existing collections, the extension of late opening, provision of automatic guide lectures, and restaurants.
The Commission reiterates its recommendations in the previous report concerning estate duty, and income tax and surtax. It is pointed out that as it is not the policy of museums to finance themselves by entrance fees, apart from minor sources, only the taxpayer and private benefactors remain. It is thus felt that all bequests of money or money's worth should be exempted from aggregation and payment of estate duty, and that this should hold even if the donor dies within a year from the making of the gift. It is also considered that tax reliefs should be made in respect of gifts of objects or money, as the present British system of taxation offers no incentive to a benefactor to give to museums and art galleries during his life-time.

Those associated with provincial museums-and there are about 800 in the British Isles-will welcome the information that the Commission hopes to complete the survey and report, with recommendations, during the summer of 1962 , possibly issuing an interim factual report some time in 1961. This will be awaited with great interest.

The report also includes an impressive survey of the individual institutions comprising the national museums in London, Edinburgh and Cardiff.

F. S. WALLIS

\section{POPULATION MOVEMENTS AND MALARIA ERADICATION}

$\mathrm{I}^{\mathrm{N}}$ the early months of 1960, a World Health Organization consultant, Mr. R. Mansell Prothero, visited the Sudan, Uganda, Kenya, Somaliland, Tanganyika, Zanzibar, Southern Rhodesia, Nigeria and Ghana to study the effect of population movements on malaria eradication programmes. In his report (W.H.O. Chron., 15, No. $5-6 ; 1961)$ he observes that, although no method of measuring the extent of population instability has yet been devised, there ean be no doubt of the high degree of such instability in Africa.

In all countries and territories visited by Prothero, there are considerable population movements from permanent villages to farms and back again. These usually involve the erection of temporary shelters for migrants on the farms. In the Sudan, for example, people move from one area to another during the cotton-picking season; in Nigeria, during the dry season, people go the valleys where there is still water to irrigate the land. Gambia receives many temporary immigrants from neighbouring countries for groundnut cultivation. Cultivation, planting and weeding coincide with the early months of the rainy season when malaria vectors are on the increase, and when temporary shelters provide suitable resting places for them.

Although the harvesting of such products as groundnuts, cocoa, and cotton attracts a considerable amount of labour, in many parts of Africa it occurs after the peak of malaria transmission. The same cannot be said of movements of labour to mining, industrial and commercial undertakings, since these occur all the year round.

Nomadic movements of pastoral tribes, which are on a larger scale than other types of population movement, occur only in certain parts of Africa, such as northern Sudan and Somalia. Fixed settlements are foreign to the way of life of these tribes; moreover, the environment in which they live com. pels many of them to wander with their flocks and herds. The only religious movement of any large size are those of the West African Mohammedans, north-east towards Mecca; these cause some convergance on the Sudan, but do not involve so many people as the internal migrations of the population of the country itself.

Apart from those connected with farming, most of these population movements occur without respect for international or political boundaries. Their effect on the stability of populations is considerable, and in fact, all malarial eradication pilot projects now in operation in Africa are hampered by them. It has so far proved impossible to start a malaria eradication programme for a whole country in Africa, because there is not one that contains population movements within its own boundaries. To keep migrants out of an area by using some kind of cordon sanitaire would not be practicable, because there are so many ways in which an African can get through natural or man-made boundaries if he wishes to do so. International co-operation in malaria eradication would only be a partial solution. These population movements are a fundamental part of the 'way of life' of the people. Some, such as pastoral nomadism, are traditional; others, such as migrant labour, are of more recent development. In either case, they cannot within a short time be stopped or easily controlled.

The situation must be accepted, and if it raises problems in malaria eradication, it will be necessary to find ways of adjusting to it. Malariologists in Africa must try to circumvent the problems that population movements raise for them in their work. But how, for example, is it possible to deal with the nomad pastoralist whose movements do not appear to follow any fixed plan, and whose huts, being mostly composed of grass and leaves, are not susceptible to effective insecticide treatment? It is clear that there 